\title{
Transition Fuels and Environmental Problems
}

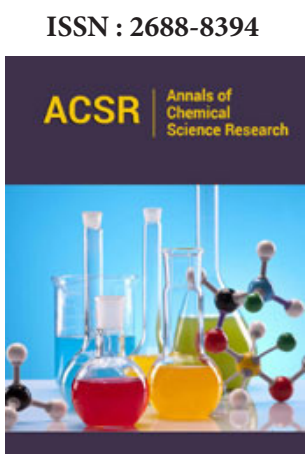

*Corresponding author: Offiong NO, Centre for Energy \& Environmental Sustainability Research (CEESR), University of Uyo, Uyo, Nigeria

Submission: 想 March 11, 2020

Published: 監March 16, 2020

Volume 2 - Issue 1

How to cite this article: Akpan PE, Offiong NO. Transition Fuels and Environmental Problems. Ann Chem Sci Res. 2(1). ACSR.000527.2020.

DOI: 10.31031/ACSR.2020.02.000527

Copyright@Offiong NO, This article is distributed under the terms of the Creative Commons Attribution 4.0 International License, which permits unrestricted use and redistribution provided that the original author and source are credited.

\author{
Akpan $\mathrm{PE}^{1}$ and Offiong $\mathrm{NO}^{2 *}$
}

${ }^{1}$ Department of Science and Technology, Akwa Ibom State Polytechnic, Ikot Osurua, Nigeria

${ }^{2}$ Centre for Energy \& Environmental Sustainability Research (CEESR), University of Uyo, Uyo, Nigeria

\section{Introduction}

According to Spiro [1] "energy use underlies virtually all environmental issues...and its access is key to a better life for people and around the world." The world currently depends on fossil fuel resources for much of its energy needs. The inevitable depletion of fossil fuel reserves and concomitant increase in atmospheric greenhouse gases are forcing a transition from fossil fuel to renewable energy sources such as solar, geothermal, wind and biomass $[2,3]$. Renewable energy sources are those which are not exhaustible, and which can provide continuous supply [4]. Other examples of renewable energy sources include wood, ocean thermal energy and tidal power. A brief description of these energy sources is provided below:

a. Solar-solar energy originates from the electromagnetic radiation from the sun to earth.

b. Geothermal energy-underground heat in the form of steam, hot water, or hot rock used to produce steam have been used as an energy source.

c. Wind-this is the energy derived from moving air used by windmills.

d. Biomass energy-this refers to direct burning of word, wastepaper, manure, agricultural wastes or any form of biomass or converting them to a fuel source. Certain microorganisms when they digest biomass in the absence of air, produce wither alcohol or methane gas, which give energy on combustion.

\section{Transition Fuels}

Transition fuels are simply those energy sources that are alternatives to fossil fuels at present pending when renewable energy sources would be fully utilized. In many instances, promoters of transition fuels are deeply focused on reducing gaseous emissions so as to mitigate global warming and climate change. It is expected that in the future, the world energy utilization will be from sources that are renewable with little or no carbon footprint. While this is work in progress, new products have emerged for sustenance during the transition. Some of the fuels include $\mathrm{CO}_{2}$-based fuels, natural gas (containing mainly methane), methanol, dimethyl ether (DME), Fisher-Tropsch-fuels and oxy-methylene ethers (OMEs). In some cases, nuclear energy is considered given its low carbon footprint. These fuels show improved properties such as high combustion efficiencies and low pollutant emissions over the whole value chain [5].

\section{Environmental problems associated with transition fuels}

These transition fuels are not devoid of environmental problems:

A. Problem 1: There are many uncertainties regarding their environmental status since comprehensive environmental and life cycle assessment are still lacking [5].

B. Problem 2: Natural gas that are blended with hydrogen pose some technical barriers. Hydrogen embrittles the steel used for natural gas pipelines, creating the potential for dangerous leaks. Advanced materials are required to solve this problem.

C. Problem 3: To get more natural gas, a recent technological development called hydraulic fracking has been introduced. Hydraulic fracking "is a process in which a mixture of water and chemicals is injected under high pressure into rock formations to release gas inside." The problem with fracking is the environmental effects on groundwater and 
greenhouse gas emissions from methane, the main component of natural gas. Harris [6] reported that fracking could also be linked to possible earthquakes.

D. Problem 4: In the case of nuclear energy which generates very low levels air pollution and greenhouse gases, environmental concerns are on the risk of major accidents and long-term storage of toxic nuclear wastes.

E. Problem 5: Biodiesel production (from raw materials such as sugarcane) is associated with the use of fertilizer and pesticides. High use of fertilizer may result in NOx emissions or eutrophication of lakes/streams.

\section{Conclusion}

As a conclusion, Harris [6] have suggested the following policy options to encourage a transition to renewable energy sources:

a. Energy research and development

b. Feed-in tariffs

c. Subsidies/favorable tax and loan terms

d. Renewable energy targets

e. Efficiency improvements and standards

\section{References}

1. Spiro TG, Stigliani WM (1996) Chemistry of the environment. Prentice Hall Publishers, Upper Saddle River, New Jersey, USA.

2. Capellán-Pérez I, Arto I, Polanco-Martínez JM, González-Eguino M, Neumann MB (2016) Likelihood of climate change pathways under uncertainty on fossil fuel resource availability. Energy \& Environmental Science 9(8): 2482-2496.

3. Turn SQ (2018) Reforming of transition fuels for the hydrogen economy. Hawaii Natural Energy Institute, Hawaii, USA.

4. Dara SS, Mishra DD (2010) A textbook of environmental chemistry and pollution control: Energy, ecology, ethics and society. S Chand Publishers, New Delhi, India.

5. Deutz S, Bongartz D, Heuser B, Katelhon A, Langenhorst LS, et al. (2018) Cleaner production of cleaner fuels: Wind-to-wheel-environmental assessment of $\mathrm{CO}_{2}$-based oxymethylene ether as a drop-in fuel. Energy \& Environmental Science 11(2): 331-343.

6. Harris JM, Roach B (2017) Energy: The greattransition. In: Environmental and Natural Resource Economics: A Contemporary Approach. Global Development and Environment Institute, Tufts University, Boston, MA, USA. 